\title{
Study on Agrometeorological Indices, Thermal and Photothermal Use Efficiency of Summer Groundnut (Arachis hypogaea L.) at Allahabad Region, India
}

\author{
Anand Kumar, Manoj Kumar Tripathi*, Virender Pal and Sunil Kumar Sharma
}

School of Forestry and Environment, SHIATS-Deemed-To-Be-University, Allahabad, India

*Corresponding author

\begin{tabular}{|l|}
\hline K e y w o r d s \\
Groundnut, Variety, \\
Date of sowing, \\
Weather \\
parameters, Yield
\end{tabular}

A B S T R A C T

An investigation on effect of sowing time on growth, phenology and yield attribute of summer groundnut (Arachis hypogaea L.) was conducted at Agrometeorological Station Farm, School of Forestry and Environment, SHIATS-Deemed-To-Be-University, Allahabad during crop season 2013. Sixteen treatment combinations with four dates of sowing $\left(1^{\text {st }}\right.$ March, $11^{\text {th }}$ March, $21^{\text {st }}$ March and $31^{\text {st }}$ March) and four varieties (HNG-69, R2(Girnar-2), HNG-10 and M-13) were tried in split plot design with four replications. The crop yield showed negative and highly significant correlations with average weathers parameters viz., maximum temperature, minimum temperature during early crop growth phases especially flowering and pegging period and the morning relative humidity, afternoon relative humidity during later crop growth phases especially pod maturity period. The crop yield showed negative and highly significant correlations with accumulated agrometeorological indices viz., growing degree days (GDD), photothermal unit (PTU), hygrothermal unit I, photo temperature and nycto temperature during early crop growth phase especially flowering period and positive during pod maturity phase, except GDD, PTU, HgTU-I and HgTU-II. The optimum maximum temperature during flowering $\left(\mathrm{P}_{3}\right)$ and pod maturity $\left(\mathrm{P}_{5}\right)$ phases were found to be $41.9{ }^{0} \mathrm{C}$ and $36.6{ }^{0} \mathrm{C}$, respectively.

\section{Introduction}

Groundnut (Arachis hypogaea L.) is an annual legume crop and a major oilseed crop of tropical and subtropical countries, which is also known as 'peanut', 'earthnut', 'monkey nut' and 'goobers'. It is the $13^{\text {th }}$ most important crop and $4^{\text {th }}$ most oilseed crop of the world. Groundnut is a widely adapted to varying agro-climatic conditions and soils, which has made its cultivation possible in most of the tropical and subtropical countries in the world. Groundnut is a $\mathrm{C}_{3}$ plant where photo respiration is very high. Groundnut is a deep rooted a distinct tap root with secondary and deeply spreading roots make it drought resistant to some extent. Groundnut is a selfpollinated crop and pollination takes place early in the morning. If rainfall occurs in the morning then pollination is affected. As soon as fertilization is complete, the flowers fade. After fertilization, peg produced. The pegs are 
positively geotropic enter in the soil. In India, about 91 percent of total groundnut area is confined to the states of Gujarat, Andhra Pradesh, Karnataka, Tamil Nadu, Maharashtra and Odisha. The rest of the area and production is scattered mainly in the states of Rajasthan, Utter Pradesh, Madhya Pradesh and Punjab. In India, the total area under groundnut cultivation was 4.93 million hectares and total production was 5.94 million tonnes with productivity of $1144 \mathrm{~kg} \mathrm{ha}^{-1}$ has been reported in the year 2010-11 (Anonymous, 2010a). Among the major groundnut states, Gujarat ranks first in production and second in area. In Utter Pradesh, the total area under groundnut cultivation was 2,61,950 hectares and total production was 2,39,000 tonnes with productivity of $1690 \mathrm{~kg} \mathrm{ha}^{-1}$ has been reported in the year 2009-10 (Anonymous 2010b). The duration of specific stages of growth shows direct relationship with temperature and for particular species this duration may be predicted through summation of mean daily air temperature (Wang, 1960), because each growth stages effected from weather parameters (Patel et al., (2010). Temperature, soil moisture, relative humidity, bright sunshine hours and solar radiation are the important weather parameters that influence the crop life cycle during summer season.

\section{Materials and Methods}

The experiment was conducted at the Agrometeorological Station Farm, School of Forestry and Environment, SHIATS-DeemedTo-Be-University, Allahabad during crop season 2013. The soil of the experiment plot was sandy loam in texture and slightly alkaline in reaction, low in organic carbon and available nitrogen, medium in available phosphorus and potassium status. Sixteen treatment combinations with four dates of sowing $\left(1^{\text {st }}\right.$ March, $11^{\text {th }}$ March, $21^{\text {st }}$ March and $31^{\text {st }}$ March) and four varieties (HNG-69, R-2
(Girnar-2), HNG-10, M-13) were tried in split plot design with four replications. The keep date of sowing in main plot and varieties as sub plot treatments. The crop was sown in line with spacing of $30 \times 10 \mathrm{~cm}$, using seed rate of $120 \mathrm{~kg} / \mathrm{ha}$ with fertilizer dose of $25 \mathrm{~kg} \mathrm{~N}$ and $50 \mathrm{~kg} \mathrm{P}_{2} \mathrm{O}_{5} / \mathrm{ha}$. Full dose of fertilizer in the form of urea and DAP was applied in furrows before sowing. Two interculturing and two hand weeding were carried out in groundnut crop to maintain weed free condition during crop season.

The crop was free form major insect pests by taking suitable plant protection measures. The five plants from net plot were selected randomly and were tagged in each treatment plots for the purpose of measured observation. The crop growth stages from each date of sowing were recorded as date of emergence, flowering, pegging, pod development and pod maturity.

Weather parameters viz., maximum temperature $\left(\mathrm{T}_{\max }\right)$, minimum temperature $\left(\mathrm{T}_{\mathrm{min}}\right)$, Relative humidity (RH I \& RH II), Bright sunshine hours (BSS) were recorded at the agrometeorological observatory located near the experiment field. The agrometeorological indices viz., growing degree days (GDD), photothermal unit (PTU), heliothermal unit (HgTU I \& II) were calculated following Chopada (2004) using base temperature of $10^{\circ} \mathrm{C}$ (Lavand, 2012).

GDD $=\sum($ Tmax + Tmin $) / 2-$ base temperature

PTU $=$ GDD $\mathrm{X} N$ (maximum possible sunshine hours)

HTU = GDD X N (Actual duration of bright sunshine)

HgTU - I \& II = GDD X Relative humidity at morning (I) and at afternoon (II) 
The effective day temperature $\left(\mathrm{T}_{\text {photo }}\right)$ and night temperature $\left(\mathrm{T}_{\text {nycto }}\right)$ were calculated following Went (1957) while Interdiurnal range of temperature $\left(\mathrm{T}_{\mathrm{IDR}}\right)$ was calculated following Wang (1960).

$\mathrm{T}_{\text {photo }}=\mathrm{T}_{\max }-1 / 4 \mathrm{X}\left(\mathrm{T}_{\max }-\mathrm{T}_{\min }\right)$

$\mathrm{T}_{\text {nycto }}=\mathrm{T}_{\max }+1 / 4 \mathrm{X}\left(\mathrm{T}_{\max }-\mathrm{T}_{\min }\right)$

$\mathrm{T}_{\mathrm{IDR}}=\left(\mathrm{T}_{\max }\right)_{\mathrm{i}}-\left(\mathrm{T}_{\min }\right)_{\mathrm{i}+1}$

Where, $\left(\mathrm{T}_{\max }\right)_{\mathrm{I}}=$ maximum temperature of the $i^{\text {th }}$ day, $\left(\mathrm{T}_{\min }\right)_{\mathrm{i}+1}=$ minimum temperature of the $(\mathrm{i}+1)^{\text {th }}$ day

\section{Results and Discussion}

\section{Agrometeorological indices}

\section{Growing degree days}

The data pertaining to accumulated heat units in different treatments are presented in Table 1. Different dates of sowing significant influenced GDD. The GDD accumulation was significantly highest in $\mathrm{D}_{1}\left(1887.14\right.$ day $\left.{ }^{0} \mathrm{C}\right)$ than other sowing dates. The minimum GDD was accumulated in $\mathrm{D}_{4}$ sowing date (1656.98 day $\left.{ }^{0} \mathrm{C}\right)$.

The GDD accumulation was highest in $\mathrm{D}_{1}$ due to longer duration of crop growing period and lowest in $\mathrm{D}_{4}$ sowing due to forced maturity caused by increase in temperature. The decrease in GDD may be due to decrease in the maturity period of the groundnut. These findings are agreement with Murty et al., (2008), and Meena and Dahama et al., (2004). The growing degree day was significant influenced by the crop varieties. The significantly highest GDD was accumulated by variety $\mathrm{V}_{1}\left(1839.18\right.$ day $\left.{ }^{0} \mathrm{C}\right)$ followed by variety $\mathrm{V}_{2} \quad\left(1809.43\right.$ day $\left.{ }^{0} \mathrm{C}\right)$. However, significantly lowest GDD was analysed in variety $\mathrm{V}_{4}\left(1738.79\right.$ day $\left.{ }^{0} \mathrm{C}\right)$. These data are those for arranged in Table 1. The interaction effect between sowing dates and different varieties was found to be non-significant for GDD accumulation. The results are with the conformity with the findings of Jadhav et al., (1990).

\section{Photothermai unit}

The photothermal unit (PTU) under various sowing dates is presented in the Table 1. Different sowing dates were found to be nonsignificant for accumulation of PTU. However, crop varieties were significantly differed for accumulation of photothermal unit (PTU). The highest PTU was obtained by variety $\mathrm{V}_{1}$ (22998.1 ${ }^{0}$ day hrs) followed by variety $V_{2}$ (22600.6 ${ }^{0}$ day hrs). However, significantly lowest PTU was recorded by variety $\mathrm{V}_{4}\left(20290.4{ }^{0}\right.$ day hrs $)$. The interaction effect between sowing dates and different varieties was found to be non-significant for PTU.

\section{Heliothermal unit}

The accumulated heliothermal unit (HTU) under various sowing dates is presented in the Table 1. Different sowing dates significantly influenced heliothermal unit (HTU). The $\mathrm{D}_{1}$ accumulated maximum heliothermal units $\left(15469.7^{0}\right.$ day hrs) to reach maturity stage. The lowest HTU was accumulated in $\mathrm{D}_{4}$ sowing date that is $13129.6^{\circ}$ day hrs. This may be due to cloudiness prevailed during the pod development stage of $\mathrm{D}_{4}$ sown crop. These results are reported by Chakravarty and Sastry (1983).

The heliothermal unit (HTU) was significant influenced by the crop varieties. The highest HTU was obtained by variety $\mathrm{V}_{1}$ (14611.3 ${ }^{0}$ day $\mathrm{hrs}$ ) followed by variety $\mathrm{V}_{2}(14459.3$ ${ }^{0}$ day hrs). However, significantly lowest HTU was recorded by variety $\mathrm{V}_{4}\left(141116^{0}\right.$ day hrs $)$. The interaction effect between sowing dates and different varieties was round to be nonsignificant for HTU. 


\section{Hygrothermal unit-I}

The accumulated morning hygrothermal unit-I required by the crop for various Phenophases under different dates of sowing are presented in Table 1. The hygrothermal unit-I significantly influenced by sowing dates. The hygrothermal unit-I was highest $\left(153927^{0}\right.$ day percent) in the $\mathrm{D}_{1}$ followed by $\mathrm{D}_{2}(149174.0$ ${ }^{0}$ day percent). The accumulation of HgTU-I was the lowest in $\mathrm{D}_{4} 34352^{\circ}$ day percent due to short crop growth period. Hygrothermal unit-I (HgTU-I) was significant influenced by crop varieties. The highest HgTU-I was obtained by variety $\mathrm{V}_{1}\left(149798{ }^{\circ}\right.$ day percent) followed by variety $\mathrm{V}_{2}\left(147339^{0}\right.$ day percent). However, significantly lowest HgTU-I was recorded by variety $\mathrm{V}_{4}\left(141361{ }^{0}\right.$ day per cent). The decrease trend was found in variety $V_{1}$ to $\mathrm{V}_{4}$ in all sowing dates due to shortening of maturity date. The interaction effect between sowing dates and different varieties was found to be not significant for HgTU-I.

\section{Hygrothermal unit-II}

The accumulated afternoon hygrothermal unitII accumulated the crop during various phenophases under different sowing dates are presented in the Table 1. The hygrothermal unit-II (HgTU-II) significantly influenced by different sowing dates. The $\mathrm{D}_{3}$ sown condition accumulated the highest hygrothermal unit-II (58309.9 ${ }^{0}$ day percent) whereas, lowest hygrothermal unit-II was accumulated by $\mathrm{D}_{4}$ sowing condition (53851.3 ${ }^{0}$ day percent). Crop varieties significantly influenced the accumulation of hygrothermal unit-II (HgTUII). The highest HgTU-II was obtained by variety $\mathrm{V}_{1}\left(59826.9^{0}\right.$ day percent) followed by variety $\mathrm{V}_{2}\left(58159.1^{\circ}\right.$ day percent). However, significantly lowest HgTU-II was obtained by variety $\mathrm{V}_{4} \quad\left(54020.9{ }^{\circ}\right.$ day percent $)$. The decrease trend was found in variety $V_{1}$ to $V_{4}$ in all sowing date variations in days taken to maturity by different varieties. The interaction effect between sowing dates and different varieties was found to be not significant for HgTU-II.

\section{Photo temperature ( $\left.\mathbf{T}_{\text {photo }}\right)$}

The photo temperature $\left(\mathrm{T}_{\text {photo }}\right)$ significantly influenced by different sowing dates (Table 1). The photo temperature was the highest in the $\mathrm{D}_{1}(4173.940 \mathrm{C})$ followed by $\mathrm{D}_{2}$ sowing condition (4057.44 0C). The lowest photo temperature was taken by $\mathrm{D}_{4}$ sowing condition (3674.39 0C). Photo temperature $\left(\mathrm{T}_{\text {photo }}\right)$ was significantly influenced by the crop varieties. The highest Photo temperature was obtained by variety $\mathrm{V}_{1}\left(4100.03{ }^{\circ} \mathrm{C}\right)$ followed by variety $\mathrm{V}_{2} \quad\left(4022.17{ }^{\circ} \mathrm{C}\right)$. However, significantly lowest photo temperature ( $\left.\mathrm{T}_{\text {photo }}\right)$, was recorded variety $\mathrm{V}_{4} \quad(3834.05 \quad \mathrm{C})$. The decrease trend was found in variety $V_{1}$ to $V_{4}$ in all sowing dates. The interaction effect between sowing dates and different varieties was found to be non-significant for photo temperature.

\section{Nycto temperature $\left(T_{\text {nycto }}\right)$}

The nycto temperature ( $T_{\text {nycto }}$ ) is significantly influenced by different sowing dates. The nycto temperature was the highest in $\mathrm{D}_{1}$ sowing condition $\left(3230.38{ }^{\circ} \mathrm{C}\right)$ followed by $\mathrm{D}_{2}$ sowing condition $\left(3190.08{ }^{\circ} \mathrm{C}\right)$. The lowest nycto temperature was taken by $\mathrm{D}_{4}$ sowing condition $\left(2962.21{ }^{\circ} \mathrm{C}\right)$. Among crop varieties the nycto temperature $\left(\mathrm{T}_{\text {nycto }}\right)$ was significantly influenced. The highest nycto temperature was obtained by variety $\mathrm{V}_{1}\left(3259.43{ }^{\circ} \mathrm{C}\right)$ followed by variety $\mathrm{V}_{2} \quad\left(3188.22{ }^{\circ} \mathrm{C}\right)$. However, significantly lowest nycto temperature $\left(\mathrm{T}_{\text {nycto }}\right)$ was recorded by variety $\mathrm{V}_{4}\left(3015.77^{\circ} \mathrm{C}\right)$. The decrease trend was found in variety $V_{1}$ to $V_{4}$ in all sowing dates due to different days taken to maturity. These data are arranged in Table 1. The interaction effect between sowing dates and different varieties was found to be nonsignificant for nycto temperature. 
Table.1 Effect of treatments on various agrometeorological indices to reach maturity stage in summer groundnut during crop season 2013

\begin{tabular}{|c|c|c|c|c|c|c|c|c|}
\hline Treatment & GDD & PTU & HTU & HgTU-I & HgTU-II & $\mathrm{T}_{\text {photo }}$ & $T_{\text {nvcto }}$ & $\mathrm{T}_{\text {IDR }}$ \\
\hline \multicolumn{9}{|c|}{ Sowing dates (D) } \\
\hline $\mathrm{D}_{1}$ & 1887.14 & 21871.8 & 15469.7 & 153927 & 58005.2 & 4173.94 & 3230.38 & 1890.63 \\
\hline $\mathrm{D}_{2}$ & 1829.70 & 22747.5 & 14728.6 & 149174 & 57923.0 & 4057.44 & 3190.08 & 1736.91 \\
\hline $\mathbf{D}_{3}$ & 1787.08 & 22438.7 & 14137.9 & 145358 & 58309.9 & 3977.82 & 3182.22 & 1591.97 \\
\hline$\overline{D_{4}}$ & 1656.98 & 20951.4 & 13129.6 & 134352 & 53851.3 & 3674.39 & 2962.21 & 1420.56 \\
\hline F-test & S & NS & $\mathrm{S}$ & S & S & S & S & S \\
\hline S.Em. \pm & 13.089 & - & 68.678 & 1036.7 & 739.305 & 33.1 & 30.034 & 5.621 \\
\hline C.D. at $5 \%$ & 29.608 & - & 155.35 & 2345.1 & 1672.31 & 74.873 & 67.937 & 12.715 \\
\hline C.V.\% & 0.52 & 3.09 & 0.34 & 0.5 & 0.92 & 0.59 & 0.68 & 0.24 \\
\hline \multicolumn{9}{|l|}{ Varieties $(\mathrm{V})$} \\
\hline$V_{1}$ & 1839.18 & 22998.1 & 14611.3 & 149798 & 59826.9 & 4100.03 & 3259.43 & 1681.38 \\
\hline$V_{2}$ & 1809.43 & 22600.6 & 14459.3 & 147339 & 58159.1 & 4022.17 & 3188.22 & 1668.63 \\
\hline $\mathbf{V}_{3}$ & 1773.51 & 22120.3 & 14281.7 & 144313 & 56082.4 & 3927.34 & 3101.48 & 1653.02 \\
\hline $\mathrm{V}_{4}$ & 1738.79 & 20290.4 & 14113.6 & 141361 & 54020.9 & 3834.05 & 3015.77 & 1637.04 \\
\hline F-test & $\mathrm{S}$ & $\mathrm{S}$ & $\mathrm{S}$ & $\mathrm{S}$ & $\mathrm{S}$ & $\mathrm{S}$ & $\mathrm{S}$ & $\mathrm{S}$ \\
\hline 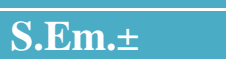 & 8.365 & 992.632 & 43.249 & 698.31 & 486.916 & 21.819 & 19.929 & 4.361 \\
\hline C.D. at $5 \%$ & 16.993 & 2016.53 & 87.86 & 1418.6 & 989.17 & 44.326 & 40.485 & 8.86 \\
\hline C.V.\% & 0.4 & 2.89 & 0.25 & 0.39 & 0.71 & 0.46 & 0.54 & 0.18 \\
\hline \multicolumn{9}{|c|}{ Interaction (D X V) } \\
\hline F-test & NS & NS & NS & NS & NS & NS & NS & NS \\
\hline S.Em.土 & - & - & - & - & - & - & - & - \\
\hline C.D. at 5\% & - & - & - & - & - & - & - & - \\
\hline
\end{tabular}

Table.2 Phenothermal index during different sowing dates

\begin{tabular}{|c|c|c|c|c|c|c|}
\hline $\begin{array}{c}\text { Sowing } \\
\text { Dates }\end{array}$ & \multicolumn{5}{|c|}{ Phenophases } & A verage \\
\hline & $\mathbf{P}_{\mathbf{1}}$ & $\mathbf{P}_{\mathbf{2}}$ & $\mathbf{P}_{\mathbf{3}}$ & $\mathbf{P}_{\mathbf{4}}$ & $\mathbf{P}_{\mathbf{5}}$ & \\
\hline $\mathbf{D}_{1}$ & 12.2 & 13.8 & 16.3 & 19.4 & 16.2 & $\mathbf{7 7 . 9}$ \\
\hline $\mathbf{D}_{2}$ & 12.3 & 14.9 & 16.6 & 19.7 & 14.9 & $\mathbf{7 8 . 4}$ \\
\hline $\mathbf{D}_{3}$ & 13.0 & 16.4 & 16.2 & 18.9 & 13.7 & $\mathbf{7 8 . 2}$ \\
\hline $\mathbf{D}_{4}$ & 16.6 & 17.2 & 19.7 & 16.4 & 12.9 & $\mathbf{8 2 . 8}$ \\
\hline
\end{tabular}

* $\mathrm{P}_{1}=$ =Emergence, $\mathrm{P} 2=$ =Flowering, $\mathrm{P} 3=$ =Pegging, $\mathrm{P} 4=$ =Pod development, $\mathrm{P} 5=$ =Pod maturity 
Table.3 Thermal and photothermal use efficiency in summer groundnut during crop season 2013

\begin{tabular}{|c|c|c|c|c|c|c|c|c|}
\hline Treatment & HUE & PTUE & HTUE & HgTUE-I & HgTUE-II & $\mathrm{T}_{\text {photo }} \mathrm{UE}$ & $\mathrm{T}_{\text {nycto }} \mathrm{UE}$ & $\mathrm{T}_{\mathrm{IDR}} \mathrm{UE}$ \\
\hline \multicolumn{9}{|c|}{ Sowing dates (D) } \\
\hline$\overline{\mathbf{D}_{1}}$ & 0.847 & 0.065 & 0.106 & 0.010 & 0.03 & 0.38 & 0.48 & 0.92 \\
\hline $\mathbf{D}_{2}$ & 0.749 & 0.058 & 0.094 & 0.009 & 0.02 & 0.34 & 0.43 & 0.82 \\
\hline $\mathbf{D}_{3}$ & 0.679 & 0.052 & 0.085 & 0.008 & 0.02 & 0.31 & 0.38 & 0.74 \\
\hline $\mathbf{D}_{4}$ & 0.625 & 0.048 & 0.079 & 0.008 & 0.02 & 0.28 & 0.35 & 0.69 \\
\hline F-test & S & S & S & S & S & S & S & S \\
\hline S.Em. \pm & 0.0132 & 0.0010 & 0.0017 & 0.0002 & 0.0001 & 0.006 & 0.008 & 0.014 \\
\hline C.D. at 5\% & 0.0300 & 0.0023 & 0.0038 & 0.0004 & 0.001 & 0.013 & 0.017 & 0.032 \\
\hline C.V.\% & 1.29 & 1.30 & 1.30 & 1.29 & 1.30 & 1.29 & 1.30 & 1.28 \\
\hline \multicolumn{9}{|l|}{ Varieties (V) } \\
\hline $\mathbf{V}_{1}$ & 0.790 & 0.064 & 0.096 & 0.010 & 0.03 & 0.36 & 0.46 & 0.79 \\
\hline $\mathrm{V}_{2}$ & 0.713 & 0.055 & 0.086 & 0.009 & 0.02 & 0.32 & 0.41 & 0.76 \\
\hline $\mathbf{V}_{3}$ & 0.762 & 0.057 & 0.099 & 0.009 & 0.02 & 0.34 & 0.43 & 0.86 \\
\hline $\mathbf{V}_{4}$ & 0.634 & 0.046 & 0.083 & 0.007 & 0.02 & 0.28 & 0.35 & 0.77 \\
\hline F-test & $\mathrm{S}$ & $\mathrm{S}$ & S & $\mathrm{S}$ & $\mathrm{S}$ & S & S & S \\
\hline S.Em. \pm & 0.0132 & 0.0010 & 0.0017 & 0.0002 & 0.000 & 0.006 & 0.007 & 0.015 \\
\hline C.D. at 5\% & 0.0267 & 0.0020 & 0.0034 & 0.0003 & 0.001 & 0.012 & 0.015 & 0.029 \\
\hline C.V.\% & 4.48 & 4.60 & 4.34 & 4.62 & 4.60 & 4.50 & 4.57 & 4.24 \\
\hline \multicolumn{9}{|c|}{ Interaction (D X V) } \\
\hline F-test & $\mathrm{S}$ & $\mathrm{S}$ & $\mathrm{S}$ & $\mathrm{S}$ & $\mathrm{S}$ & $\mathrm{S}$ & S & $\mathrm{S}$ \\
\hline S.Em. \pm & 0.026 & 0.002 & 0.003 & 0.000 & 0.001 & 0.012 & 0.015 & 0.029 \\
\hline C.D. at $5 \%$ & 0.053 & 0.004 & 0.007 & 0.001 & 0.002 & 0.024 & 0.030 & 0.059 \\
\hline
\end{tabular}

Table.4 Correlation coefficient between agrometeorological indices and different phenophases in summer groundnut during crop season 2013

\begin{tabular}{|c|c|c|c|c|c|}
\hline \multirow{2}{*}{$\begin{array}{l}\text { Weather } \\
\text { parameters }\end{array}$} & \multicolumn{5}{|c|}{ Phenophases } \\
\hline & Emergence & Flowering & Pegging & $\begin{array}{c}\text { Pod } \\
\text { development }\end{array}$ & Pod maturity \\
\hline GDD & 0.0758 & $-0.8049 * *$ & $-0.7045^{* *}$ & $0.5243 *$ & 0.2727 \\
\hline PTU & -0.0480 & $-0.7137 * *$ & $-0.7237 * *$ & 0.4113 & 0.2729 \\
\hline HTU & 0.1567 & $-0.5846^{*}$ & $-0.7750 * *$ & $0.5720^{*}$ & $0.7864 * *$ \\
\hline HgTU-I & 0.0893 & $-0.7886 * *$ & $-0.6450 * *$ & $0.5930 *$ & 0.3485 \\
\hline HgTU-II & 0.3340 & $-0.6092 *$ & $0.6109 *$ & $-0.4978 *$ & $-0.6015^{*}$ \\
\hline $\mathbf{T}_{\text {nycto }}$ & 0.0043 & $-0.7398 * *$ & $-0.5424^{*}$ & $-0.7991 * *$ & $0.8152 * *$ \\
\hline $\mathbf{T}_{\text {photo }}$ & 0.2306 & $-0.7143 * *$ & $-0.6025^{*}$ & 0.1198 & $0.8376^{* *}$ \\
\hline $\mathbf{T}_{\mathrm{IDR}}$ & $0.6339 * *$ & -0.4680 & -0.4316 & $0.7502 * *$ & $0.8419 * *$ \\
\hline
\end{tabular}




\section{Inter diurnal temperature $\left(\mathrm{T}_{\mathrm{IDR}}\right)$}

The inter diurnal temperature $\left(\mathrm{T}_{\mathrm{IDR}}\right)$ was significantly influenced by different sowing dates. The highest inter diurnal temperature was in the $\mathrm{D}_{1}$ sowing $\left(1890.63{ }^{\circ} \mathrm{C}\right)$ followed by $\mathrm{D}_{2}$ sowing $\left(1736.91{ }^{0} \mathrm{C}\right)$. The lowest inter diurnal temperature was taken by $\mathrm{D}_{4}\left(1420.56{ }^{0} \mathrm{C}\right)$. The crop varieties significantly influenced the inter diurnal temperature $\left(\mathrm{T}_{\mathrm{IDR}}\right)$. The highest inter diurnal temperature was obtained by variety $\mathrm{V}_{1}$ $\left(1681.38{ }^{\circ} \mathrm{C}\right)$ followed by variety $\mathrm{V}_{2}(1668.63$ $\left.{ }^{0} \mathrm{C}\right)$. However, significantly lowest inter diurnal temperature $\left(\mathrm{T}_{\mathrm{IDR}}\right)$ was recorded by variety $\mathrm{V}_{4}$ $\left(1637.04{ }^{0} \mathrm{C}\right)$. These data are arranged in Table 1. The interaction effect between sowing dates and different varieties was found to be nonsignificant.

\section{Phenothermal index}

The phenothermal index (PTI) for different dates of sowing dates are presented in the Table 2. The phenothermal index was the highest in $\mathrm{D}_{4}$ sowing (82.8 degree days/day) whereas, the lowest phenothermal index was analysed in $\mathrm{D}_{1}$ sowing (77.9 degree days/day). The phenothermal index increase from emergence to pod development in $\mathrm{D}_{1}$ to $\mathrm{D}_{2}$ sowing date. The average phenothermal index was increased in $\mathrm{P}_{1}$ to $\mathrm{P}_{4}$ phenophases in different sowing date.

\section{Thermal and photothermal use efficiency}

\section{Heat use efficiency}

The heat use efficiency (HUE) significantly influenced by different sowing dates (Table 3). The heat use efficiency was highest in the $D_{1}$ $\left(0.847 \mathrm{~kg} / \mathrm{ha} /{ }^{0} \mathrm{C}\right.$ day $)$ followed by $\mathrm{D}_{2}(0.749$ $\mathrm{kg} / \mathrm{ha} /{ }^{0} \mathrm{C}$ day). The lowest heat use efficiency was taken by $\mathrm{D}_{4}\left(0.625 \mathrm{~kg} / \mathrm{ha} /{ }^{0} \mathrm{C}\right.$ day $)$. These results are analogous with Meena and Dahama (2004) and Sahu et al., (2007). The heat use efficiency (HUE) was significantly influenced by crop varieties. The highest HUE was obtained by variety $\mathrm{V}_{1}\left(0.790 \mathrm{~kg} / \mathrm{ha} /{ }^{0} \mathrm{C}\right.$ day $)$ followed by variety $\mathrm{V}_{3}\left(0.762 \mathrm{~kg} / \mathrm{ha} /{ }^{0} \mathrm{C}\right.$ day $)$. However, significantly lowest HUE was recorded by variety $\mathrm{V}_{4}\left(0.634 \mathrm{~kg} / \mathrm{ha} /{ }^{0} \mathrm{C}\right.$ day $)$. These data are arranged in Table 3 . The interaction effect between sowing dates and different varieties was found to be significant for HUE.

\section{Photothermal use efficiency}

The photothermal use efficiency (PTUE) was significantly influenced by sowing dates (Table 3 ). The photothermal use efficiency was highest $\left(0.065 \mathrm{Kg} / \mathrm{ha} /{ }^{0} \mathrm{C}\right.$ day) in the $\mathrm{D}_{1}$ sowing condition followed by $\mathrm{D}_{2}$ sowing condition $\left(0.058 \mathrm{Kg} / \mathrm{ha} /{ }^{0} \mathrm{C}\right.$ day). The lowest photothermal use efficiency was taken by $\mathrm{D}_{4}$ sowing condition $\left(0.048 \mathrm{Kg} / \mathrm{ha} /{ }^{0} \mathrm{C}\right.$ day $)$. The interaction effect between sowing dates and different varieties for PTUE was found to be significant for PTUE.

\section{Heliothermal use efficiency}

The heliothermal use efficiency (HTUE) significantly influenced by sowing dates (Table $3)$. The heliotherrnal use efficiency was the highest in the $\mathrm{D}_{1}(0.106 \mathrm{Kg} / \mathrm{ha} /$ degree day hrs $)$ followed by $\mathrm{D}_{2}(0.094 \mathrm{Kg} / \mathrm{ha} /$ degree day hrs $)$. The lowest heliothermal use efficiency was taken by $\mathrm{D}_{4}(0.079 \mathrm{Kg} / \mathrm{ha} /$ degree day hrs $)$. The results obtained with accordance with Sahu et al., (2007). Among crop varieties, the heliothermal use efficiency (HTUE) was significantly differed. The highest HTUE was obtained by variety $\mathrm{V}_{3}(0.099 \mathrm{Kg} / \mathrm{ha} /$ degree day hrs) followed by variety $\mathrm{V}_{1}(0.096 \mathrm{Kg} / \mathrm{ha} /$ degree day hrs). However, significantly lowest HTUE was recorded by variety $\mathrm{V}_{4}(0.083$ $\mathrm{Kg} / \mathrm{ha} /$ degree day hrs). The interaction effect between sowing dates and different varieties for HTUE was found to be significant.

\section{Hygrothermal use efficiency-I (HgTUE-I)}

The Hygrothermal use efficiency-I (HgTUE-I) significant influenced by sowing dates (Table $3)$. The hygrothermal use efficiency was the highest in the $\mathrm{D}_{1}(0.010 \mathrm{~kg} / \mathrm{ha}$ degree day \%) followed by $\mathrm{D}_{2}(0.009 \mathrm{~kg} / \mathrm{ha}$ degree day $\%)$. The lowest hygrothermal use efficiency was 
taken by $\mathrm{D}_{4}(0.008 \mathrm{~kg} / \mathrm{ha}$ degree day \%). Among crop varieties, the hygrothermal use efficiency (HgTUE-I) was significantly differed. The highest HgTUE-I was obtained by variety $\mathrm{V}_{1}(0.010 \mathrm{~kg} / \mathrm{ha}$ degree day $\%)$ followed by variety $\mathrm{V}_{2}(0.009 \mathrm{~kg} / \mathrm{ha}$ degree day $\%)$. However, significantly lowest HTUE was recorded by variety $\mathrm{V}_{4}(0.007 \mathrm{~kg} / \mathrm{ha}$ degree day $\%)$. The interaction effect between sowing dates and different varieties for HgTUE-1 was found to be significant.

\section{Hygrothermal use efficiency-II (HgTUE-II)}

The hygrothermal use efficiency-II (HgTUE-II) is significant influenced by sowing dates (Table 3 ). The hygrothermal use efficiency was highest $(0.03 \mathrm{~kg} / \mathrm{ha}$ degree day $\%)$ in the $\mathrm{D}_{1}$ followed by $\mathrm{D}_{2}(0.02 \mathrm{~kg} / \mathrm{ha}$ degree clay $\%)$. The lowest hygrothermal use efficiency was taken by $\mathrm{D}_{4}$ $(0.02 \mathrm{~kg} / \mathrm{ha}$ degree day \%). Among crop varieties, hygrothermal use efficiency (HgTUEII) was found to significant. The highest HgTUE-II was obtained by variety $\mathrm{V}_{1}(0.03$ $\mathrm{kg} /$ ha degree day \%) followed by variety $\mathrm{V}_{2}$ (0.02). However, significantly lowest HgTUE-II was recorded by variety $\mathrm{V}_{4}(0.02 \mathrm{~kg} / \mathrm{ha}$ degree day \%). The interaction effect between sowing dates and different varieties for HgTUE-II found to be significant.

Nycto temperature use efficiency $\left(T_{\text {nycto }} \mathrm{UE}\right)$ ${ }^{\mathbf{0}} \mathbf{C}$

The nycto temperature use efficiency $\left(\mathrm{T}_{\text {nycto }} \mathrm{UE}\right)$ significant influenced by sowing dates (Table $3)$. The $D_{1}$ sown crop recorded highest nycto temperature use efficiency $(0.48)$ followed by $\mathrm{D}_{2}$ sowing condition $(0.43)$. The lowest nycto temperature use efficiency was taken by $\mathrm{D}_{4}$ (0.35). Among varieties, the nycto temperature use efficiency ( $\left.T_{\text {nycto }} U E\right)$ was significantly varied. The highest $\mathrm{T}_{\text {nycto }} \mathrm{UE}$ was obtained by variety $\mathrm{V}_{1}(0.46)$ followed by variety $\mathrm{V}_{3}(0.43)$. However, significantly lowest $\mathrm{T}_{\text {nycto }} \mathrm{UE}$ was recorded by variety $\mathrm{V}_{4}(0.35)$. The interaction effect between sowing dates and different varieties was found to be significant.
Photo temperature use efficiency $\left(\mathrm{T}_{\text {photo }} \mathrm{UE}\right)$ ${ }^{\mathbf{0}} \mathrm{C}$

The photo temperature use efficiency ( $\left.\mathrm{T}_{\text {photo }} \mathrm{UE}\right)$ significant influenced by sowing dates (Table 3 ). The photo temperature use efficiency was the highest in the $D_{1}(0.38)$ followed by $D_{2}$ (0.34). The lowest photo temperature use efficiency was taken by $\mathrm{D}_{4}(0.28)$. Among crop varieties, the photo temperature use efficiency ( $\mathrm{T}_{\text {photo }} \mathrm{UE}$ ) was significant influenced. The highest $\mathrm{T}_{\text {photo }} \mathrm{UE}$ was obtained by variety $\mathrm{V}_{1}$ (0.36) followed by variety $\mathrm{V}_{3}(0.34)$. However, significantly lowest $\mathrm{T}_{\text {photo }} \mathrm{UE}$ was recorded by variety $\mathrm{V}_{4} \quad(0.28)$. The interaction effect between sowing dates and different varieties was found to be significant for $\mathrm{T}_{\text {photo }} \mathrm{UE}$.

\section{Inter diurnal temperature use efficiency $\left(\mathrm{T}_{\mathrm{IDR}} \mathrm{UE}\right)^{0} \mathrm{C}$}

The inter diurnal temperature use Efficiency ( $\mathrm{T}_{\mathrm{IDR}} \mathrm{UE}$ ) significant influenced by sowing dates and presented in Table 3. The inter diurnal temperature use efficiency was the highest in the $\mathrm{D}_{1}$ sowing condition $(0.92)$ followed by $\mathrm{D}_{2}$ sowing condition (0.82). The lowest inter diurnal temperature use efficiency was taken by $\mathrm{D}_{4}$ sowing condition (0.69). Among crop varieties, the inter diurnal temperature use efficiency $\left(\mathrm{T}_{\mathrm{IDR}} \mathrm{UE}\right)$ was significant varied. The highest $T_{\text {IDR }} \mathrm{UE}$ was obtained by variety $\mathrm{V}_{3}$ (0.86) followed by variety $\mathrm{V}_{1}(0.79)$. However, significantly lowest $\mathrm{T}_{\mathrm{IDR}} \mathrm{UE}$ was recorded by variety $V_{2}$ (0.76). The interaction effect between sowing dates and different varieties was found to be significant for $\mathrm{T}_{\mathrm{IDR}} \mathrm{UE}$.

\section{Correlation analysis}

\section{Agrometeorological indices Vs. phenophases}

The correlation coefficients between accumulated agrometeorological indices and different phenophases are presented in Table 4. A highly significant and negative correlation was noted between GDD and different phenophases viz. flowering (-0.80), pegging stage $(-0.70)$, while a significant and positive 
correlation was noticed during pod development stage (0.52). Highly significant and negative correlation was noticed between PTU and pegging stage. A highly significant and positive correlation was noted between HTU and pod maturity stage (0.78), while a highly significant and negative correlation was seen during flowering and pegging stage. These results are reported by Brar et al., (1999). A significant and positive correlation between morning hygrothermal unit and pod development stage was noticed (0.59). While a highly significant and negative correlation was observed during flowering stage (-0.79) and pegging (-0.64). A significant and positive correlation was detected between afternoon hygrothermal unit and pegging phase (0.61), while a significant and negative correlation was noticed during flowering, pod development and pod maturity stages. A highly significant and negative correlation was analysed between nycto temperature and pod development phase (0.79). A highly significant and positive correlation was noticed between photo temperature and pod maturity stage (0.83), while a highly significant and negative correlation was display during flowering (0.71). A highly significant and positive correlation was analyzed between Inter diurnal temperature was show during emergence, pod development stages.

\section{References}

Anonymous (2010 a). State wise area, production and yield per hectare in India." Directorate of Agriculture Gujarat state Gandhinagar.
Anonymous (2010 b). "District wise area, production and important food crop and yield per hectare crops in Gujarat state." Directorate of Agriculture, Gujarat state Gandhinagar.

Brar, A. S., Dhingra, K. K. and Kaul, J.N. (1999). Phenological behaviour and heat unit requirement of groundnut (Arachis hypogaea L) genotypes under two dates of sowing during summer season. Ind. J. Agri. Sci., 69(6): 419-423.

Jadhav, A. S. Mundhe, M. S and Gaikwad, C. B. (1990). Influence of sowing dates of summer groundnut varieties. J. Mah. Agric. Univ., 15(2): 214-217.

Meena, R. P. and Dahama, A. K. (2004). Relevance of thermal units in deciding sowing time and yield prediction of groundnut (Arachis hypogaea L.) under irrigated condition of western Rajasthan. J. Agromet., 69 (1): 62-69.

Murty, N. S., Singh, R. K. and Roy, S. (2008). Influence of weather parameters on growth and yield of amaranth in Uttarakhand region. J. Agromet., (special issue-part 2), 384-387.

Patel, G.G.; Patel, H.R.; Pandey, V.; Shekh, A.M.; Patel, J.S.; Vadoaria, R.P.; Bhatt, B.K. and Shroff J.C. (2010). Influence of weather parameters on pod yield of groundnut in middle Gujarat agroclimatic region. J. Agromet., 12(1): 74-76.

Sahu, D.D., Chopada, M. C. and Patoliya, B. M. (2007). Determination of sowing time for chickpea varieties in south Saurashtra, Ind. J. Agromet., 9(1): 68-73.

Wang, J. Y. (1960). A critique of the heat unit approaches to plant response studies. Ecology 41: 785-790.

\section{How to cite this article:}

Anand Kumar, Manoj Kumar Tripathi, Virender Pal and Sunil Kumar Sharma. 2018. Study on Agrometeorological Indices, Thermal and Photothermal Use Efficiency of Summer Groundnut (Arachis hypogaea L.) at Allahabad Region, India. Int.J.Curr.Microbiol.App.Sci. 7(05): 1889-1897. doi: https://doi.org/10.20546/ijcmas.2018.705.222 